Dansk Ultralyddiagnostisk Selskab

\title{
DUDS videnskabelige møde i Århus 29/1-20
}

Dansk Ultralyddiagnostisk Selskabs videnskabelige møde ved Billeddiagnostisk Årsmøde i Århus 29/2 var igen i år ganske velbesøgt.

Programmet var endnu engang utrolig alsidigt. Dagen startede med spændende oplæg fra Michel B Hellfritzsch og Mads Henriksen fra AUH, som gennemgik normal anatomi og diagnostiske muligheder ved ultralyd af underekstremiteterne efterfulgt af patologiske fund. Der blev fremvist mange flotte ultralydsbilleder.

Christian B. Laursen fra OUH havde herefter en flot gennemgang af lungeultralydskanning og ultralyds vigtige plads som modalitet ved lungesygdomme. Niklas K. Rasmussen fra CAMES fortalte om sit ph.d projekt omhandlende simulationstræning ved pleuracentese og vurdering af ultralydkompetancer.

Efter frokost handlede det om ultralyd af nedre abdomen. Torben Lorentzen fra Herlev Universitetshospital gennemgik fornemt differentialdiagnostik af nedre abdomen og havde vanen tro film af elegante interventioner.

Professor Søren Rafaelsen fra Vejle Universitetshospital havde flot oplæg om et af sine forskningsområder transrectal ultralyd (TRUS) og staging af rectumcancer og gennemgik nyeste guidelines. TRUS af rectum tumorer er især vigtig, hvis minimal invasiv rectumkirurgi overvejes. TRUS-staging har dog ikke stejl indlæringskurve, og først efter ca. 50 skanninger er nøjagtigheden på et reproducerbart niveau.

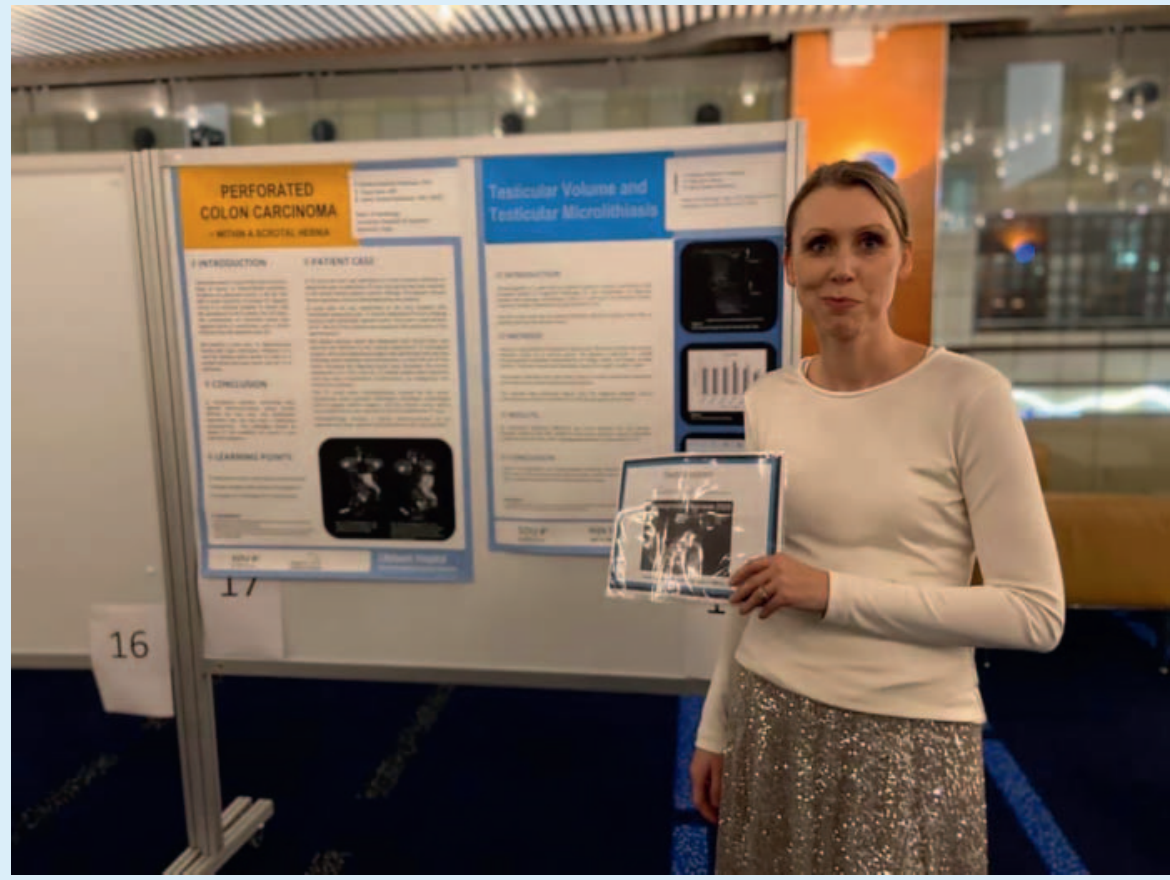

Ph.d, radiograf og DUDS-redaktør Malene Roland Pedesen vinder af bedste poster ved Årsmødet: Måling af testikelvolumen med ultralyd hos mænd med testicular microlithaisis sammenholdt med kontroller.

Abelone Sakse fra RH gennemgik fornemt brugen af transabdominal ul ved gynækologiske lidelser og havde præcise vejledninger til, hvornår henvisning til gynækologisk ultralyd og vurdering er nødvendig.

Sidste foredrag var igen Torben Lorentzen, der gennemgik evidensen om tumorseeding efter biopsi ud fra internationale og egen data. Seeding er en velbeskrevet risiko, hvorfor indikationen for biopsi af fokale processer, altid bør træffes i et multidisciplinært samarbejde.
Dagen blev afsluttet med en altid godt besøgt Hands-on ultralydsession, hvor diverse sponsorer velvilligt havde stillet deres high-end maskiner til rådighed og skaffet figuranter.

Efter det videnskabelige program var der DUDS generalforsamling. Referat på DUDS.dk

Tusind tak til overlæge Merete Juhl Kønig for endnu engang at planlægge et relevant og spændende program. 